\title{
Setting Restrictions on Extensive Reading: A Preliminary Short-Term Investigation
}

\section{Takayuki Nakanishi Dokkyo University}

\begin{abstract}
Although empirical studies support extensive reading (ER) as a method of reading instruction, instructors often let students choose what they want to read. Thus, instructors do not exercise any control over the difficulty level of students' reading materials. The present study attempts to address this issue by setting restrictions on students' choice of reading materials. Forty-two third-year Japanese university students participated in this one-semester study. The first group (free-reading group) was permitted to read books of any length, whereas the second group (restricted-reading group) had to choose books of at least 1,000 words in length. The findings revealed that both groups read a similar number of books over the same period of time. However, the restricted-reading group read more words than the free-reading group. Comments from the students revealed their positive attitudes toward and enjoyment of ER. Pedagogical implications are also considered in terms of the implementation of ER.
\end{abstract}

多読はリーディングの教授法の1つとして多くの実証研究結果から確証 を得ているが、基本的に教員は、学生に本を自由に選択させている。つま り、多くの現場で本の難易度に対するコントロールはされていないのが 現状である。本論は、学生を2つのグループに分け、本の選択にレベルを 設定し、どのような違いが見られるかを考察した。42名の大学3年生を対 象とし、自由に本を選択できるグループと、1,000語以上の本しか選ぶこと のできないグループに分け、1学期間の推移を見た。結果的に、どちらの グループもほぼ同じ冊数を読んだが、語数に制限があつたため、後者の 方が前者のグループよりも多く読んだことが分かった。質問紙のコメント からは、どちらの学生も多読に興味を持って取り組んでいたことが示唆 された。また、多読の実施という点での教育的意義も考察した。

$\mathrm{n}$ English as a Foreign Language (EFL) educational contexts, a lack of English language input represents one of the major obstacles in developing and maintaining English proficiency (Shiki, 2011; Takase, 2010). To overcome this difficulty, many instructors utilize extensive reading (ER) both in and outside the classroom to develop students' proficiency. ER is defined as "reading in quantity and in order to gain a general understanding of what is read. It is intended to develop good reading habits, to build up knowledge of vocabulary and structure, and to encourage a liking for reading" (Richards \& Schmidt, 2002, pp. 193-194). Many empirical studies in second language acquisition also support the use of ER as a pedagogical method to increase reading speed and reading comprehension (e.g., Beglar, Hunt, \& Kite, 2012; McLean \& Rouault, 2017; Nakanishi \& Ueda, 2011). Furthermore, there have been numerous researchers who have written about the benefits and management of ER (Day \& Bamford, 1998; Nakanishi \& Ueda, 2011; Nuttall, 2005).

The availability and choice of books to read are important components of ER and also have been addressed in studies. When conducting ER, Day and Bamford (2002) wrote that when a variety of reading materials are available on a wide range of topics at different levels of linguistic difficulty, students should choose what they want to read, and read unassisted. In the same line of thought, Asraf and Ahmad (2003) wrote that students should be given an opportunity to choose books that they prefer. They also stated that "it is thus important that teachers be sensitive to their students' affective state and conduct their English classes in a relaxed and supportive atmosphere, especially when it comes to extensive reading, which is aimed at having students read extensively for pleasure" (p. 98). Many researchers seem to accept as a rule that students must choose their own books with ER, but this belief is based on very little empirical evidence.

In the previous literature on ER, Day and Bamford (1998) recommended that reading materials be well within the linguistic competence level of the students. In terms of the levels of books, this could be a way to handle ER. Nakanishi and Ueda (2011) described the way that instructors dealt with in-class ER for students. They brought short books first so that it was not demanding for students to begin reading. Gradually, longer texts were introduced, which is a typical example of how ER is conducted. In many cases, however, instructors let students choose whatever they wanted to read, with no control over reading levels. It remains unclear whether letting students choose the difficulty levels of their own books would lead to more student reading. Thus, the present study attempts to fill this gap by setting restrictions on students' choice of reading materials and their difficulty levels. 


\section{Research Questions}

The purpose of the present study was to investigate the participants' perceptions of restrictions on their choice of reading material. The following two research questions were thus posed:

RQ1 Are there any differences in ER outcomes between a group without any restrictions on reading material and a group with restrictions?

RQ2 What are the perceptions of ER among students without restrictions on reading material and those with restrictions?

\section{Method}

\section{Participants}

Forty-two third-year Japanese university students majoring in economics participated in this one-semester study. The classes began at the beginning of April, ended at the end of July, and met 15 times throughout one semester. Two intact classes that had been sorted according to TOEIC scores participated. The first group (free-reading group) consisted of 25 students with TOEIC scores ranging from 520 to 555 . The second group (restricted-reading group) consisted of 17 students with TOEIC scores ranging from 560 to 825 . Table 1 shows the means and standard deviations for the TOEIC scores of each group. There were three students who had high scores in the restricted-reading group: Two had scores of 705 and 750 respectively, and one had a score of 825 , resulting in a large $S D$. All participants attended only one English class per week, which was a content-based academic reading and writing class focused on developing critical reading and thinking skills. The same instructor taught both of the two classes the same way. The only difference was ER input, which is described in detail below.

\section{Instruments}

\section{M-Reader}

Tagane, Naganuma, and Dougherty (2018) identified several types of academic dishonesty in ER through student interviews. One of the types they discussed involved students reading only the beginning and end of a book or skimming a book by trying to get an overall idea of the story when writing a book report. M-Reader (www.mreader. org) was chosen because it could be a beneficial way to prevent this kind of dishonesty. M-Reader is a free online tool that allows teachers to manage ER classes. It features quiz functions that test students' understanding of the books they read. They need to receive a certain percentage of correct answers to receive a pass status, which enables their book to be counted as read. Therefore, students have to read the entire book to achieve a high score in M-Reader.

\section{Questionnaire}

A short questionnaire was created to investigate the students' perceptions of and reactions to ER. There were five items on the questionnaire:

1. Did you enjoy extensive reading? (多読を楽しめましたか)

2. Do you think your reading speed and understanding of English books increased as a result of extensive reading?

(英語の本を読む際のスピードや理解度は向上した と感じますか)

3. Do you want to continue to read in English? (今後も英語の本を読みたいと思いますか)

4. How did you feel about the freedom to choose books?

（読む際の指定がないことについてどう感じました か)

5. How did you feel about extensive reading in general? (多読全般に関する意見を聞かせてください)

The above five items were asked only to the free-reading group. When given to the restricted-reading group, item 4 was changed to "How did you feel about the restriction of choosing only books with more than 1,000 words?” (読む際の1,000 語以上の設定については、どう感じましたか). The questionnaire was administered in Japanese at the end of the spring semester during the final 15 minutes of regular class time and collected at the end of the class.

Table 1. Descriptive Statistics of the TOEIC Scores for the Two Groups

\begin{tabular}{lcccccc}
\hline Groups & $\mathrm{N}$ & $M(\min , \max )$ & $S D$ & $S E$ & Skewness & Kurtosis \\
\hline Free-reading & 25 & $540.20(520,555)$ & 10.94 & 2.19 & -0.55 & -0.61 \\
Restricted-reading & 17 & $620.88(560,825)$ & 74.12 & 17.98 & 1.79 & 2.73 \\
\hline
\end{tabular}




\section{Procedure}

Both the free-reading group $(n=25)$ and the restricted-reading group $(n=17)$ engaged in inclass ER for 10 minutes at the beginning of class every week. Students were allowed to bring books from the school library or to borrow from the books brought by the instructor. Each book had a sticker describing how many words the book contained, which helped the students when they were choosing a book. The only distinction among the two groups was that the free-reading group was supposed to start with easier books, whereas the restricted-reading group had to choose books with more than 1,000 words. Nation (2015) suggests that learners engaged in ER should know at least $98 \%$ of the words in the text. The present study was exploratory and aimed to investigate the nature of ER. Therefore, this suggestion was not strictly followed.

The students were given the goal of reading 30,000 words and 20 or more books by the end of the semester. The goal for the word count and number of books was set because in the past, some students read only two books that resulted in over 30,000 words. Thus, it was necessary to establish both the word count and the number of books. Students were also encouraged to read outside of class to reach the target. To ensure that the students were reading as they reported, M-Reader was required to monitor their reading and used to keep reading logs.

Student progress was checked by the instructor at the end of every month to facilitate and monitor students' reading progress and frequency. The instructor reported who had reached the target and announced the top three students to the class to encourage further reading at the end of every month.

\section{Preliminary Analyses}

An independent-samples $t$-test was conducted to evaluate the differences in the English proficiency levels of the students in the two groups. To check the assumptions, Levene's test indicated that the equality-of-variance assumption was violated. The $t$ value did not assume equal variance, $t(16.48)=4.46$, $p<.01$, meaning that the two groups were statistically different before the study began in terms of their TOEIC scores. For this study it was unavoidable that the two groups differed in proficiency.

\section{Results}

\section{Extensive Reading Progress}

Tables 2 and 3 show the students' reading progress in each group and summarizes the number of books and words read at the end of each month. For example, in Table 2, Student 1 read 20 books and 39,088 words by the end of May. As is evident from both tables, the highest achievers started out by reading a large number of books and words, but the students at the bottom of the table needed to be encouraged.

Table 2. Free-Reading Group Progress

\begin{tabular}{|c|c|c|c|c|c|c|}
\hline \multirow[b]{2}{*}{ 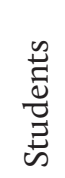 } & \multicolumn{2}{|c|}{ May } & \multicolumn{2}{|c|}{ June } & \multicolumn{2}{|c|}{ July } \\
\hline & $\begin{array}{l}\tilde{v} \\
\frac{v}{8} \\
\ddot{D}\end{array}$ & $\begin{array}{l}0 \\
0 \\
3 \\
3\end{array}$ & $\begin{array}{l}\ddot{y} \\
\ddot{0} \\
\infty\end{array}$ & $\begin{array}{l}\infty \\
0 \\
3 \\
3\end{array}$ & $\frac{\tilde{v}}{8}$ & $\begin{array}{l}0 \\
0 \\
3 \\
3\end{array}$ \\
\hline 1 & 20 & 39,088 & 3 & 11,002 & 0 & 0 \\
\hline 2 & 35 & 40,077 & 3 & 4,345 & 0 & 0 \\
\hline 3 & 11 & 22,154 & 5 & 11,022 & 1 & 789 \\
\hline 4 & 11 & 24,424 & 7 & 5,775 & 4 & 3,530 \\
\hline 5 & 15 & 19,891 & 4 & 13,654 & 0 & 0 \\
\hline 6 & 12 & 11,988 & 7 & 14,495 & 2 & 6,650 \\
\hline 7 & 20 & 15,402 & 17 & 17,261 & 0 & 0 \\
\hline 8 & 9 & 16,090 & 14 & 15,893 & 2 & 636 \\
\hline 9 & 17 & 18,027 & 5 & 13,370 & 0 & 0 \\
\hline 10 & 22 & 12,228 & 14 & 10,266 & 8 & 8,506 \\
\hline 11 & 13 & 12,764 & 10 & 10,538 & 5 & 7,292 \\
\hline 12 & 11 & 24,868 & 6 & 3,914 & 6 & 1,767 \\
\hline 13 & 22 & 15,257 & 10 & 12,596 & 4 & 2,337 \\
\hline 14 & 7 & 17,218 & 2 & 7,856 & 1 & 5,054 \\
\hline 15 & 6 & 12,708 & 2 & 16,396 & 2 & 968 \\
\hline 16 & 5 & 13,109 & 0 & 0 & 1 & 9,614 \\
\hline 17 & 16 & 10,003 & 9 & 8,180 & 1 & 2,200 \\
\hline 18 & 1 & 324 & 0 & 0 & 3 & 13,546 \\
\hline 19 & 2 & 6,428 & 1 & 6,390 & 0 & 0 \\
\hline 20 & 6 & 3,506 & 0 & 0 & 4 & 5,345 \\
\hline 21 & 7 & 4,630 & 4 & 2,985 & 1 & 806 \\
\hline 22 & 0 & 0 & 1 & 74 & 2 & 6,050 \\
\hline 23 & 3 & 2,112 & 0 & 0 & 0 & 0 \\
\hline 24 & 3 & 757 & 0 & 0 & 2 & 365 \\
\hline 25 & 0 & 0 & 0 & 0 & 0 & 0 \\
\hline
\end{tabular}

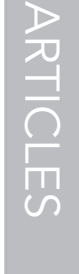


Table 3. Restricted-Reading Group Progress

\begin{tabular}{|c|c|c|c|c|c|c|}
\hline \multirow[b]{2}{*}{ 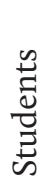 } & \multicolumn{2}{|r|}{ May } & \multicolumn{2}{|c|}{ June } & \multicolumn{2}{|c|}{ July } \\
\hline & 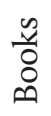 & $\begin{array}{l}\text { Don } \\
3 \\
3\end{array}$ & $\begin{array}{l}\mathscr{y} \\
\dot{0} \\
\dot{0}\end{array}$ & $\begin{array}{l}0 \\
0 \\
3 \\
3\end{array}$ & $\begin{array}{l}\mathscr{y} \\
\stackrel{y}{0} \\
\infty\end{array}$ & $\begin{array}{l}n \\
0 \\
3 \\
3\end{array}$ \\
\hline 1 & 13 & 101,520 & 5 & 30,849 & 2 & 7,589 \\
\hline 2 & 32 & 63,131 & 6 & 14,087 & 2 & 5,112 \\
\hline 3 & 14 & 48,219 & 6 & 7,222 & 6 & 24,330 \\
\hline 4 & 11 & 32,412 & 8 & 19,342 & 5 & 17,274 \\
\hline 5 & 20 & 38,869 & 2 & 8,273 & 2 & 10,009 \\
\hline 6 & 14 & 36,532 & 3 & 8,118 & 6 & 10,732 \\
\hline 7 & 15 & 30,878 & 5 & 11,588 & 1 & 1,422 \\
\hline 8 & 35 & 33,101 & 0 & 0 & 6 & 10,640 \\
\hline 9 & 13 & 24,940 & 3 & 2,913 & 8 & 14,613 \\
\hline 10 & 5 & 9,574 & 13 & 22,061 & 4 & 9,962 \\
\hline 11 & 24 & 41,521 & 0 & 0 & 0 & 0 \\
\hline 12 & 11 & 23,047 & 5 & 7,406 & 6 & 10,722 \\
\hline 13 & 17 & 19,311 & 9 & 16,497 & 3 & 5,147 \\
\hline 14 & 12 & 19,653 & 4 & 4,034 & 10 & 13,455 \\
\hline 15 & 12 & 20,111 & 5 & 9,887 & 4 & 6,477 \\
\hline 16 & 16 & 17,465 & 5 & 10,914 & 6 & 7,152 \\
\hline 17 & 18 & 28,771 & 2 & 2,690 & 0 & 0 \\
\hline
\end{tabular}

To better compare the data, the same number of students (the top 17) were taken from each group, as shown in Table 4. Looking at only Tables 2 and 3 , it appears that students in the restricted-reading group read much more than the other group, given that the top two students read 139,958 words and
82,330 words, respectively. Table 4 shows, however, that both groups read a similar number of books $(M$ $=24.1$ in the free-reading group, and $M=25.5$ in the restricted-reading group) by the end of the semester. The only difference was the number of words read, resulting from the restriction that students in the restricted-reading group had to read longer books.

\section{Questionnaire Results}

Table 5 shows the questionnaire results for the first three questions. The results indicated that most students in each group enjoyed ER and noticed some improvement in their reading speed and understanding of English books. Consequently, most of them expressed that they wanted to continue to read in English. Because ER was a required course objective, they had to do it whether they liked it or not. However, the results indicated the students' positive attitudes toward ER.

Table 5. Results of the First Three Questionnaire Items

\begin{tabular}{ccccc}
\hline & \multicolumn{2}{c}{ Free-reading } & \multicolumn{2}{c}{ Restricted-reading } \\
\cline { 2 - 5 } & Yes (\%) & No (\%) & Yes (\%) & No (\%) \\
\hline Q1 & $20(80)$ & $5(20)$ & $15(88)$ & $2(12)$ \\
Q2 & $20(80)$ & $5(20)$ & $14(82)$ & $3(18)$ \\
Q3 & $22(88)$ & $3(12)$ & $13(76)$ & $4(24)$ \\
\hline
\end{tabular}

The last two questionnaire items were open-ended questions, which asked the free-reading group about their opinions on the freedom to choose books and the restricted-reading group about their opinions on the restriction to books with more than 1,000 words. Finally, the last question asked both groups about their general opinions of ER. Revealing and informative comments including positive

Table 4. Group Comparison of Top 17 Students

\begin{tabular}{lrrrrrrrr}
\hline \multirow{2}{*}{ Groups } & \multicolumn{2}{c}{ May } & \multicolumn{2}{c}{ June } & \multicolumn{2}{c}{ July } & \multicolumn{2}{c}{ Total } \\
\cline { 2 - 8 } & \multicolumn{1}{c}{ Books } & \multicolumn{1}{c}{ Words } & Books & Words & Books & Words & Books & Words \\
\hline Free (M) & 14.82 & 19135.06 & 6.94 & 10386.06 & 2.18 & 2902.53 & 24.00 & 32423.65 \\
(SD) & 7.48 & 8841.50 & 4.80 & 4839.06 & 2.40 & 3282.04 & 10.40 & 6739.84 \\
Restricted (M) & 16.59 & 34650.29 & 4.76 & 10345.94 & 4.18 & 9096.24 & 25.53 & 54092.47 \\
(SD) & 7.61 & 21529.42 & 3.23 & 8245.82 & 2.81 & 6257.10 & 6.16 & 26830.74 \\
\hline
\end{tabular}

Note: $n=17$. 
and negative responses were selected for inclusion and translated into English for this manuscript.

For the free-reading group, the majority of students $(88 \%)$ answered that they liked having the freedom to choose their own books. Some comments included: "It was good to have the freedom to choose books, and it was nice to know my level." "By starting from a very easy level of books, I felt it was a bit difficult to move to the next level." "Since there was no restriction, I chose some books that were also movies so that I was familiar with the stories." "With the freedom to choose what I wanted, I tended to only read easier books."

Regarding the restricted-reading group, the results were mixed. A few students expressed feeling limited by the rule, but at the same time, others expressed a sense of enjoyment when reading more demanding books. Some comments included the following: "Because of the rule of choosing books with more than a 1,000-word count, I really felt limited in my choice of books." "It was tough to choose books under that condition." "The rule seemed to work for me." "If I read an easy book, there may not be much of a story, so I like to read books with a certain amount of words." "The rule did not bother me." "I thought it was difficult at first, but I began to realize that reading books with less than a 2,000word count was not that hard for me."

With respect to ER in general, as shown in Table 5, many students seemed to enjoy ER and felt some improvement in their reading speed and understanding of English books in both groups. Specifically, the students wrote the following comments: "A little bit of pressure to read helps." "I think my reading speed and understanding of English books improved, but it was hard to meet the target." "I liked the fact that I could choose books I like." "It gave me a good opportunity to read English books for the first time." There were some comments about the use of M-Reader as well: "I felt a sense of disappointment when reading a book that was not listed in M-Reader."

\section{Discussion and Conclusion}

The present study investigated whether there were any differences between a free-reading group and a restricted-reading group in a university EFL class, as well as students' perceptions of ER in general and restricted-ER specifically. Regarding the two research questions, the results indicated that both groups read a similar number of books over the same period. However, due to the restriction of choosing books with more than 1,000 words, the restricted-reading group read more words than the free-reading group. Comments from the students revealed their positive attitudes toward and enjoyment of ER. The findings of the present study can be summarized in the following two points:

1. Based on the results of the questionnaire, most students were not bothered by having a restriction on the choice of books. A few students expressed the feeling of limitation due to the fact they had difficulty of finding books because of the rule. However, most students liked the idea of having to choose more difficult books.

2. The restricted-reading group generally appeared to not have trouble starting the term by reading more difficult (in this case, longer) books. Thus, it was not necessary to make them begin with shorter books. This could help them to read more in the long run.

It is intriguing to note that all the students in the restricted-reading group reached the target of 30,000 words and 20 books. However, in the free-reading group, only 15 students read more than 30,000 words and only 13 students out of 25 read more than 20 books. This is interesting in light of the fact that they were able to start with easier (shorter) books. Requiring students to read longer books might encourage them to read more and thus reach their reading goal more easily. Although the focus of this study was not to discuss proficiency, it should also be noted again that the restricted-reading group had higher TOEIC scores at the outset of the study, which might be a possible confounding variable. Furthermore, using similar proficiency groups might produce contrasting outcomes. Thus, proficiency level should be controlled in future research. Notwithstanding, if the evidence is supported, this increased amount of text should lead to more gains. Yamashita (2015) reinforces this idea in the following claim:

ER is reading for pleasure. Only when people enjoy reading, do they continue to read for its own reward. Research shows that pleasure not only motivates readers but also has positive effects on their cognitive functioning and conceivably facilitates comprehension and learning. All these things contribute, in turn, to large quantities of reading. (p. 173)

Consistent with the assertion made by Yamashita in the above quote, the results of the present study seem to indicate that if students enjoy reading, this could lead to a larger quantity of reading. As we can see in a comment from a student, "If I read an easy book, there may not be much of a story." In my experience with ER instruction throughout the years, for university students with a certain level of 
English proficiency books need to be intellectually stimulating. Longer texts might better provide this stimulation, which could lead to more reading.

\section{Acknowledgement}

I would like to thank the editor and anonymous reviewers for their constructive feedback on earlier versions of this manuscript.

\section{References}

Asraf, R. M., \& Ahmad, I. S. (2003). Promoting English language development and the reading habit among students in rural schools through the guided extensive reading program. Reading in a Foreign Language, 15(2), 83-102. Retrieved from http://nflrc.hawaii.edu/rfl/ October2003/mohdasraf/mohdasraf.html

Beglar, D., Hunt, A., \& Kite, Y. (2012). The effect of pleasure reading on Japanese EFL learners' reading rates. Language Learning, 62(3), 665-703. doi: 10.1111/j.14679922.2011.00651.x

Day, R. R., \& Bamford, J. (1998). Extensive reading in the second language classroom. Cambridge, England: Cambridge University Press.

Day, R. R., \& Bamford, J. (2002). Top ten principles for teaching extensive reading. Reading in a Foreign Language, 14(2), 136-141. Retrieved from http://nflrc. hawaii.edu/rfl/October2002/day/day.html

McLean, S., \& Rouault, G. (2017). The effectiveness and efficiency of extensive reading at developing reading rates. System, 70, 92-106. doi:10.1016/j.system.2017.09.003

Nakanishi, T., \& Ueda, A. (2011). Extensive reading and the effect of shadowing. Reading in a Foreign Language, 23(1), 1-16. doi:0.1016/j.system.2017.09.003

Nation, P. (2015). Principles guiding vocabulary learning through extensive reading. Reading in a Foreign
Language, 27(1), 136-145. Retrieved from http://nflrc. hawaii.edu/rfl/April2015/discussion/nation.pdf

Nuttall, C. (2005). Teaching reading skills in a foreign language. Oxford, England: Macmillan Education.

Richards, J. C., \& Schmidt, R. (2002). Longman dictionary of language teaching and applied linguistics (3rd ed.). London: Person Education.

Shiki, O. (2011). Effects of extensive reading on reading speed and comprehension among Japanese university students. Kwansei Gakuin University Humanities Review, 16, 29-38. Retrieved from https://ci.nii.ac.jp/ncid/ AA11120702

Tagane, Y., Naganuma, N., \& Dougherty, P. (2018). Academic dishonesty in extensive reading programs: Stories and strategies from student interviews. The Language Teacher, 42(1), 9-12. Retrieved from https://www. jalt-publications.org/files/pdf-article/42.1tlt-art2.pdf

Takase, A. (2010). Eigo tadoku tacho shido manyuaru [Instruction manual for extensive reading and listening in English]. Tokyo: Taishukan.

Yamashita, J. (2015). In search of the nature of extensive reading in L2: Cognitive, affective, and pedagogical perspectives. Reading in a Foreign Language, 27(1), 168-181. Retrieved from https://eric.ed.gov/?id=EJ1059816

Takayuki Nakanishi received
his Ed.D. in TESOL from
Temple University. He teaches
in the Interdepartmental
(Zenkari) English Program
at Dokkyo University. His
current research topics include
extensive reading, willingness
to communicate, and language
testing. He can be reached at
tnakanis@dokkyo.ac.jp.

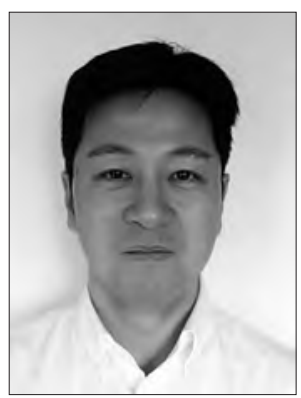

\section{JALT Publications at JALT2018 in Shizuoka}

diversity 8 inclusion

\#jalt2018
As usual, our editorial and production staff will be playing a vital role at the annual conference. Whether you're interested in getting published, would like to volunteer some time and learn a new skill, or have a project you need some help with, we're sure you'll find something of interest.

\section{Volunteering with JALT Publications}

Saturday, Nov 24, 11:00 AM - 12:30 PM in the Tenji Gallery (6F)

In this 90-minute poster session, we will show you what joining our team would entail, plus an overview of the kind of work you could be doing.

\section{How to get published in JALT Publications}

Sunday, Nov 25, 1:05 PM - 2:05 PM in Room 1202

Everything you wanted to know about getting an article published in any of our three publications. Editors from each publication will explain what kind of content we are looking for, how to submit, plus offer some advice for enhancing your acceptance prospects.

Plus, look for our JALT Publications table which will be open throughout the conference in the main hall. Drop by for a chat. You might even get some chocolate! 